\title{
Anguilliform fish reveal large scale contamination by mine trace elements in the coral reefs of New Caledonia
}

Xavier Bonnet ${ }^{1}$, Marine J. Briand ${ }^{1,2}$, François Brischoux ${ }^{1}$, Yves Letourneur ${ }^{2}$, Thomas Fauvel $^{1}$, Paco Bustamante ${ }^{3}$

1. Centre d'Etudes Biologiques de Chizé, CEBC-CNRS UPR 1934, 79360 Villiers en Bois, France

2. Université de la Nouvelle-Calédonie, Laboratoire LIVE, LABEX Corail, BP R4, 98851 Nouméa cedex, New Caledonia

3. Littoral Environnement et Sociétés (LIENSs), UMR 7266 CNRS-Université La Rochelle, 2 rue Olympe de Gouges, F-17000 La Rochelle, France

Correspondence: Xavier Bonnet ; Tel +33 549097879 ; Fax +33 549096111 ; email bonnet@cebc.cnrs.fr 


\begin{abstract}
Due to intensive mining activity, increasing urbanization and industrialisation, vast amounts of contaminants are discharged into the lagoon of New Caledonia, one of the largest continuous coral reef systems and a major biodiversity hot spot. The levels of 11 trace element concentrations were examined in the muscles of predator fish in the south-western lagoon (moray eels and congers). These species are sedentary, widespread, abundant, and they are easily collected using sea snake sampling technique. We found the highest mean and maximal concentrations of different trace elements ever found in coral fish, notably regarding trace elements typical from mining activity (e.g., mean values for $\mathrm{Cr}$ and $\mathrm{Ni}$ respectively: 5.53 $\pm 6.99 \mu \mathrm{g} \cdot \mathrm{g}^{-1}\left[\max , 35.7 \mu \mathrm{g} \cdot \mathrm{g}^{-1}\right]$ and $\left.2.84 \pm 3.38 \mu \mathrm{g} \cdot \mathrm{g}^{-1}\left[\max , 18.0 \mu \mathrm{g} \cdot \mathrm{g}^{-1}\right]\right)$. Results show that important trace element contamination extends throughout the lagoon to the barrier reef, following a concentration gradient from the oldest nickel factory (Nouméa).
\end{abstract}

Keywords: Trace elements; chromium; nickel; lagoon; mines; sea kraits 


\section{Introduction}

The lagoons of New Caledonia, SW Pacific Ocean spread over a very large area $\left(24,000 \mathrm{~km}^{2}\right)$. They are one of the largest sanctuaries for the marine diversity of the planet; it is therefore of prime importance to identify and assess potential threats to these biodiversity hotspots (Myers et al. 2000).

Increasing world demand for strategic metals, nickel (Ni) and cobalt (Co) for instance (Manheim 1986; Parkinson 2005), resulted in an intense exploitation of ores, the construction of new factories and the opening of new open sky mines in New Caledonia. Currently, Ni and Co extraction necessitates processing extremely large amounts of, garnierites, laterites and saprolites, typical ores with low $\mathrm{Ni}$ and $\mathrm{Co}$ content (e.g. 1.5\% of $\mathrm{Ni}$ in some mines, http://www.sln.nc). This involves total forest clearing of vast land surfaces, and thus entails strong erosion because the climate regime of New Caledonia is characterized by an alternation of dry and wet seasons, episodic cyclones, and torrential hydrological regimes (Pesin et al., 1995). For instance, the mines and nickel factory complex recently established in the Bay of Prony (Goro-Nickel, Vale Inco, 22 ${ }^{\circ} 19^{\prime} \mathrm{S}-166^{\circ} 55^{\prime} \mathrm{E}$ ) spreads out over $500 \mathrm{~km}^{2}$; in addition the factory will discharge 10 million cubic meters per year of effluents in the lagoon (Massabuau et al. 2006; http://www.vale.nc/activites/i_usine). Another large nickel factory (SLN, Société Le Nickel) situated in the Nouméa harbour is functioning since more than a century and is provisioned by seven mining sites spread across New Caledonia (http://www.sln.nc). The overall mining activities generate massive sediment deposits (Bird et al. 1984; Ambatsian et al. 1997; Ouillon et al. 2010; Garcin et al. 2013) and a marked metal contamination of the coastal seawaters (Hédouin et al. 2009) that may threaten coral reefs (Walker \& Ormond 1982, Rogers 1990).

However, possible environmental impact of mine industry on coral reefs remains unclear. Indeed, Nouméa (the main city) and surroundings are fast developing urbanized and industrialized areas where approximately 250,000 peoples exert strong environmental pressure (Cantin et al. 2007; Lewis et al. 2009). Large amounts of polluted waters are directly discharged into the sea. The capacities of the existing water-treatment plants are critically insufficient ( $<50 \%$ of the requirements, A2EP 2009). The respective impacts of related mining activities compared to other anthropogenic activities on the reef ecosystems have not been quantified. Although biomonitoring surveys have been carried out to examine some of these issues (Metian et al. 2008, 2013; Chouvelon et al. 2009; Hédouin et al. 2009), the impact of urban and industrial pollution on the reef ecosystems in the lagoon of New Caledonia is still a major issue. No information is available regarding large scale 
contaminations (either regarding trace element or persistent organic pollutants, POPs) or large scale environmental impact caused by pollution (Lewis et al. 2012; Rhind 2009).

The respective signatures associated with metallic contaminants stemming from urban activities versus Ni exploitation industries are different (Mihaylov et al. 2000; Hédouin et al. 2008; Metian et al. 2008; Hao et al. 2013). Theoretically, this difference provides a means to distinguish the sources of contamination. In practice contamination processes are often complex and unclear when examined across large spatial scales and different taxa are generally used to monitor geographical variations of bioavailable metal concentrations in their environment (Rainbow 1995; Bustamante et al. 2003). Using widely distributed organisms accessible all year round may provide comparative data across the entire lagoon and would permit to take into account seasonal fluctuations (Burger 2006). Importantly, the selected organisms must be sedentary to ensure that information is spatially precise. Further, using predators enables to integrate underlying trophic levels. Finally, a low-cost, efficient and fast sampling (thus simple) technique is desired.

In New Caledonia, anguilliform fish fulfil these criteria. These predators are widespread and abundant in the whole lagoon (Ineich et al. 2007, Brischoux and Bonnet 2008). Following a pelagic larval stage, they settle on the seafloor and become sedentary (Abrams et al. 1983). More generally, fish are considered as efficient bio-indicators to assess contamination in marine ecosystems (Gopal et al. 1997; van der Oost et al. 2003; Ashraf et al. 2012). Recent researches showed that using specialized top-predators (sea kraits, Laticauda spp.), large numbers of anguilliform fish can be easily collected all year round in the coral reefs of the western Pacific Ocean (Reed et al. 2002; Brischoux et al. 2007, 2009a, 2009b; Bonnet 2012). Two species of amphibious sea kraits (Laticauda laticaudata and L. saintgironsi) are very abundant and widespread in New Caledonia (Bonnet 2012). Tens of thousands of snakes prospect the seafloor around their home islet and come back on land to digest where they can be easily captured. They swallow their prey whole; a gentle forced regurgitation enabled to collect the fish without consequence for the snakes (Fauvel et al. 2012). They are phylopatric and sedentary (Brischoux et al. 2009c). Using the network of sea krait colonies spread across the entire lagoon, including coastal sites and remote islets, most of the reef ecosystems can be monitored with a high spatial resolution (Bonnet 2012).

Although many contamination studies have been conducted in fish, concentration levels of some important trace elements such as $\mathrm{Co}, \mathrm{Cr}, \mathrm{Mn}, \mathrm{Ni}, \mathrm{Se}$, and $\mathrm{V}$ have rarely been investigated (Eisler, 2010; Metian et al. 2013). These later elements were analyzed in the present study to generate baseline data on sedentary tropical fish. The first mandatory issue to 
gauge the possible usefulness of anguilliform fish to probe contamination status of the lagoon is to examine to what extent anguilliform fish actually accumulate trace elements: very low concentrations or a lack of variation (e.g. among individuals, sites...) would make these organisms useless for ecotoxicology investigations. Consequently, the following questions were examined in the present study: (i) Do anguilliform fish accumulate trace element contaminants? (ii) Do contamination levels vary spatially? And, (iii) do contaminant levels correlate differentially with respect to mining or urban sources?

\section{Materials and methods}

\section{$\underline{\text { Study sites }}$}

Study sites were situated in the Southwest lagoon, encompassing an important $\sim 25 \mathrm{~km}$ spatial gradient between the coast and the barrier reef (Fig 1). Anguilliform fish were sampled during two main periods: summers 2005 and 2011. We aimed to assess presumably heavily contaminated sites (e.g. Kuendu beach, nearby a nickel factory and the main urban and industrialised area, Figure 1) and presumably less/not impacted sites (e.g. Amédée Island, nearby the barrier reef and thus largely influenced by the open ocean, Figure 1). From 2005 to 2011, in the course of a long-term study, several sites where added (Bonnet 2012). For analyses three main site categories were considered along the coast-barrier reef gradient (Figure 1): a) near the mainland (2 coastal sites, CS), b) intermediate situation between the coast and the barrier reef ( 3 mid-lagoon sites, MS), c) remote site near the barrier reef (1 barrier reef site, BS).

\section{$\underline{\text { Fish samples }}$}

Anguilliform fish were obtained from sea snakes, L. laticaudata and L. saintgironsi, via gentle forced regurgitation (see Brischoux et al. 2007 for details). Each prey item was identified to the nearest taxonomic levels (Böhlke et al. 1999; Smith 1999a, b; Smith and McCosker 1999, see Brischoux et al. 2007). In the current study a random sub-sample of 80 fish was taken among more than 1,500 prey and thus represented the main prey species consumed by the two species of sea kraits (see Brischoux et al. 2007, 2009a). The head was lacking in roughly $50 \%$ of the samples, sometimes half of the body was also lacking, consequently five identifications at the species level were problematical (Brischoux et al. 2007; Table 1). Table 1 provides a list of the prey examined. Trace elements were analysed in 
80 fish belonging to seven species, among which 50 were collected in 2005 and 30 in 2011 (Table 1). The respective foraging ecology of the two sea krait species provides complementary information and a means to assess different seafloors (e.g. soft bottoms versus hard reefs; Brischoux et al. 2007).

\section{Tissues examined}

The fish were not immediately dissected, they were stored in the field at $-25^{\circ} \mathrm{C}$ and they were later lyophilised in the laboratory. For analyses, 200 to 400mg of dorsal tissues were removed from the dried specimens; therefore, the tissues represented in the sampling were essentially muscles (e.g. very small bones were possibly included). Digestion is highly polarized in sea kraits, important parts of the prey are usually not degraded by digestive fluids (i.e. still covered with skin) whereas one third of the prey are totally intact (Brischoux et al. 2007). We systematically used well preserved parts of the fish. Liver and kidneys where trace element concentrations are usually the highest were not sampled because lyophilisation precluded isolating easily these small organs. Importantly, using muscles provided a mean for comparison with a recent study that also analyzed trace element contamination in the muscles of 22 reef fish species (Metian et al. 2013).

\section{Contaminant assays}

The total $\mathrm{Hg}$ concentrations in the powder obtained from the tissues were determined by analyzing $\mathrm{Hg}$ directly with an Advanced Mercury Analyzer (ALTEC AMA 254) on aliquots ranging from 5 to $50 \mathrm{mg}$ of dry sample weighed to the nearest $0.01 \mathrm{mg}$ (Bustamante et al., 2006). The analysis of $\mathrm{Ag}, \mathrm{As}, \mathrm{Cd}, \mathrm{Co}, \mathrm{Cr}, \mathrm{Cu}, \mathrm{Fe}, \mathrm{Mn}, \mathrm{Ni}, \mathrm{Pb}, \mathrm{Se}, \mathrm{V}$ and $\mathrm{Zn}$ required an extra step in the preparation protocol. From 150 to $300 \mathrm{mg}$ of each sample were microwave digested in a mixture of $3 \mathrm{ml}$ of suprapure nitric acid (VWR/Merck) and $1 \mathrm{ml}$ of suprapure chloridric acid (VWR/Merck), and then diluted to $25 \mathrm{ml}$ with deionized water. These 13 elements were then analyzed by Inductively Coupled Plasma Atomic Emission Spectrometry (Varian Vista-Pro ICP-OES) and Mass Spectrometry (ICP-MS II Series Thermo Fisher Scientific). To avoid trace element contamination, all glass and plastic utensils used were washed with detergent, soaked in a bath of mixed nitric $\left(35 \mathrm{ml} . \mathrm{l}^{-1}\right)$ and chlorhydric $\left(50 \mathrm{ml}^{-1} \mathrm{l}^{-1}\right)$ acids for a minimum of $24 \mathrm{~h}$, rinsed 3 times in deionized (Milli-Q quality) water and dried in an oven at $50^{\circ} \mathrm{C}$ before use.

Accuracy and reproducibility of the preparation were tested by preparing analytical blanks and replicates of lobster hepatopancreas (TORT-2) and dog-fish liver (DOLT-3) reference 
standards (National Research Council, Canada) along with each set of samples. Results for the certified reference materials were in good agreement with the certified values and recovery rates varied from $83 \%$ to $109 \%$. The detection limits $\left(\mu \mathrm{g} \mathrm{g}^{-1}\right.$ dry wt) were $0.005(\mathrm{Hg}), 0.02$ (Ag, Cd, Co, Cr, Pb), 0.1 (Cu, Mn, Se), 0.2 (As), 0.3 (Ni), 0.33 (V), and 3.3 (Fe, Zn). Trace element concentrations are expressed in $\mu \mathrm{g} \cdot \mathrm{g}^{-1}$ of dry weight (dw).

\section{$\underline{\text { Data analyses }}$}

Possible interferes by $\mathrm{ArC}$ or $\mathrm{ClO}$ did not influence $\mathrm{Cr}$ and $\mathrm{Ni}$ analyses using ICP-MS as shown by the accurate CRM references in all tests. As the data were not normally distributed (Shapiro Wilk tests, P-values < 0.05), Log transformed data to meet normality prior analyses were used. For comparisons across studies trace element concentrations were presented as non-transformed values in Tables and figures. Two species of sea kraits were used to sample fish, but they forage in different sea floors (Brischoux et al. 2007); analyses failed to reveal a sea snake species effect for two major trace elements associated with $\mathrm{Ni}$ industry however (Ni and Co). Statistics were performed using Statistica 10.0 (Statsoft 1984-2011).

\section{Results}

\section{Trace element concentrations in fish}

All the trace elements assessed were detected in the fish, in variable concentrations however (Table 2). For instance, Fe and $\mathrm{Zn}$ were the most abundant elements whereas low mean concentrations of $\mathrm{Ag}$ and $\mathrm{Hg}$ were observed (Table 2). Very high maximal values of trace elements were found in several individuals (e.g. As, $\mathrm{Cr}, \mathrm{Cu}, \mathrm{Mn}, \mathrm{Ni}$; respectively, $118 \mu \mathrm{g}^{-\mathrm{g}^{-1}}$, $35.7 \mu \mathrm{g} . \mathrm{g}^{-1}, 19.2 \mu \mathrm{g} . \mathrm{g}^{-1}, 19.9 \mu \mathrm{g} . \mathrm{g}^{-1}$ and $18.0 \mu \mathrm{g} . \mathrm{g}^{-1} \mathrm{dw}$, Table 2). Overall, considering mean and maximal values, concentrations of most trace elements were relatively elevated (Table 2). In the sampling, the coefficient of variation of trace element concentrations ranged from $28 \%$ for V to $296 \%$ for $\mathrm{Ag}$. Some elements varied slightly (i.e. $\mathrm{Hg}, \mathrm{Se}, \mathrm{V}$, and $\mathrm{Zn}$ ) whereas Ag, As, $\mathrm{Cr}, \mathrm{Ni}$ and $\mathrm{Pb}$ showed high $\mathrm{CV}$.

For several trace elements no statistical difference was found among the different fish species (Figure 2). For example Ni or Co concentrations were not significantly different between the fish species (ANOVA with trace element concentrations as the dependent variable and fish species as the factor, $\mathrm{F}_{6,73}=2.077, \mathrm{P}=0.066$ and $\mathrm{F}_{6,73}=0.666, \mathrm{P}=0.677$, respectively); therefore, for these trace elements the fish species were pooled for several analyses. For other trace 
elements (e.g. As: $\mathrm{F}_{6,73}=14.674, \mathrm{P}<0.001$ ), significant differences were found among fish species precluding pooling them for analyses (Figure 2).

\section{Associations between trace elements}

Concentrations of trace element typically released by nickel exploitation (e.g. $\mathrm{Ni}, \mathrm{Co}, \mathrm{Cr}, \mathrm{Mn}$ ) were correlated (Figure 3). Similarly, concentrations of trace elements usually found nearby urban areas (e.g. $\mathrm{Ag}, \mathrm{Cu}$ ) were correlated (Figure 3). More precisely, $\mathrm{Cr}$ and $\mathrm{Ni}$ concentrations were highly correlated $\left(r=0.80, \mathrm{~F}_{1,}{ }_{78}=144.93, \mathrm{P}<0.001\right.$; Figure 3$)$. Ni concentrations also correlated with $\mathrm{Co}\left(\mathrm{r}=0.63, \mathrm{~F}_{1}, 78=50.22, \mathrm{P}<0.001\right), \mathrm{Fe}\left(\mathrm{r}=0.76, \mathrm{~F}_{1}\right.$, $78=106.43, \mathrm{P}<0.001)$, and $\mathrm{Mn}\left(\mathrm{r}=0.28, \mathrm{~F}_{1,78}=6.05, \mathrm{P}=0.016\right)$ but not with other trace elements (all $\mathrm{P}>0.15$; Figure 3 ). To identify the main contributors to the variation in $\mathrm{Ni}$ concentrations, a backward stepwise regression analyses was performed by including the other trace elements (only those where $\mathrm{N}=80$ included). Three trace elements were retained in the final model: Co, $\mathrm{Cr}$ and $\mathrm{Fe}\left(\mathrm{r}^{2}=0.82\right)$.

Among other trace elements, $\mathrm{Ag}, \mathrm{Cd}, \mathrm{Cu}, \mathrm{Pb}$ and $\mathrm{Zn}$ are usually recognised as contaminants that originate from urban sources (Martin et al. 1988; Sañudo-Willhelmy and Flegal 1992; Callender and Rice 2000). Using backward stepwise regression with $\mathrm{Cu}$ as the dependent variable, two trace elements were retained in the final model: $\mathrm{Pb}$ and $\mathrm{Zn}\left(\mathrm{r}^{2}=0.66\right)$. Variations in $\mathrm{Ag}$ and $\mathrm{Pb}$ concentrations were explained respectively by variations in $\mathrm{Cd}$ and $\mathrm{Cu}$ concentrations $\left(\mathrm{r}^{2}=0.26\right.$ and 0.54 respectively); yet most of the variance remained unexplained for "urban" trace elements.

\section{Spatial and annual variations}

Focusing on $\mathrm{Co}$ and $\mathrm{Ni}$ (two elements that did not show fish species effect) and comparing the sites with sufficient sample size ( $\mathrm{N}>10$ fish) along the coast-barrier reef gradient (Kuendu Signal - Amédée, Figure 1), significant effects (ANOVA with Ni concentrations as the dependent variable and site as the factor: $\mathrm{F}_{2,63}=6.92, \mathrm{P}=0.002$ ) were detected. Post-hoc tests revealed that the fish originating from the site near the nickel factory (Kuendu) were the most contaminated $(\mathrm{P}<0.005)$, with no significant difference between the fish from the two other sites $(\mathrm{P}=0.281)$. Using Co concentrations, the fish from Kuendu were the most contaminated (same design ANOVA, $\mathrm{P}=0.003$, post-hoc tests $\mathrm{P}<0.01$ ). Considering the strong correlations between $\mathrm{Ni}$ and $\mathrm{Co}$ concentrations, this later result was expected. Further analyses including years as an additional factor led to similar trends, showing that the year of sampling had no effect in the fish examined. Using the main site categories (CS, MS, BS), and hence 
increasing both sample size and spatial coverage, provided similar results showing significant differences along the gradient from the coast to the barrier reef $\left(\mathrm{F}_{2,77}=5.90, \mathrm{P}=0.004\right.$ for $\mathrm{Ni}$; $\mathrm{F}_{2,77}=10.90, \mathrm{P}<0.001$ for Co; all post-hoc tests $\mathrm{P}<0.001$; Figure 4).

For other trace elements (e.g. Cr, Fe), fish species effects precluded robust spatial and time analyses (Table 1). However, disregarding this caveat, crude investigations suggested significant costal/barrier reef contamination gradient with the highest values near the factory (all $\mathrm{P}<0.001$ ). For other trace elements that are not associated with Ni industry (e.g. Ag, Cd, $\mathrm{Fe}, \mathrm{Pb}, \mathrm{Zn}$ ) no clear spatial patterns was detected. For example, the fish from Signal (a midlagoon site, MS) exhibited the highest Fe concentrations. Nonetheless, the fish sampled in the most remote site (barrier reef site, BS) systematically exhibited lower values.

\section{Discussion}

The main objective of this study was to assess large scale contamination by trace elements in one of the main marine biodiversity hotspot of the planet - the lagoon of New Caledonia (Myers et al. 2000) - subjected to possible contamination by one of the world largest Niindustry (New Caledonia is ranked among the four major $\mathrm{Ni}$ producers). Previous investigations suggested that contamination by trace elements was limited to benthic animals belonging to low trophic levels and living in the seafloors situated near the main Ni-factory. Most studies were limited to coastal sites and focused on algae, bivalves and ascidians (Monniot et al. 1994; Hédouin et al. 2007, 2008, 2009, 2011; Metian et al. 2008). They revealed substantial local contamination by trace elements associated with $\mathrm{Ni}$ exploitation $(\mathrm{Ni}, \mathrm{Cr}, \mathrm{Co}$, and $\mathrm{Mn}$ ). In contrast, studies carried out on pelagic organisms (i.e. nautiluses and marine mammals) did not reveal evidences of $\mathrm{Ni}$ contamination out of the lagoon (Bustamante et al. 2000, 2003; Pernice et al. 2009). A recent study performed on a sample of 62 individuals belonging to 22 neritic fish species (including grazers and predators) reported low concentrations of the trace elements typical from mining activity and a lack of significant difference between sites (Metian et al. 2013). Yet, this study was essentially based on fish captured near the coast, only 5 specimens originated from a roughly defined area of the southern lagoon, and the barrier reef area was not sampled (see Metian et al. 2013 for details). The present study is thus complementary by focusing on predatory fish and encompassing a wide spatial scale, from the coast to the barrier reef.

Results on benthic predatory anguilliform fish suggest that $\mathrm{Ni}$ and $\mathrm{Cr}$ contamination occur in coral reef on large spatial scales in New Caledonia. Concentrations of $\mathrm{Co}, \mathrm{Cr}$ and $\mathrm{Ni}$ were 
particularly elevated in comparison to the data reported in other reef fish, either considering New Caledonia or fish from other reef ecosystems (Denton et al. 1986; Eisler, 2010; Metian et al. 2013). A comparison with the values recently reported in 22 fish species in New Caledonia lagoon and using similar assay methodology shows that anguilliform fish exhibit higher concentrations of mine trace elements (Figure 5). Moreover, mean and maximal concentrations of $\mathrm{Cr}, \mathrm{Mn}$ and $\mathrm{Ni}$ observed in the muscle-tissues of anguilliform fish largely exceeded those specifically measured in the liver of other fish (Figure 5 and Table 2 in Métian et al. 2013); suggesting a fortiori that moray eels and congers were highly contaminated.

Several reasons might explain why anguilliform fish exhibited very high concentrations of trace elements. Moray eels and congers are sedentary predators that forage on the seafloor (as their reptilian predators, Brischoux et al. 2009c). Trace elements might be more concentrated in the sediment/coral matrix used by anguilliform fish compared to the water column situated above where the 22 other fish species were sampled. This also suggests that mine trace elements were readily bioavailable for the anguilliform fish from the dissolved phase and that they were retained efficiently in fish tissues as shown experimentally for Co and $\mathrm{Cr}$ (Jeffree et al. 2008). In addition, trace elements can be transferred and accumulated through the food chain up to anguilliform fish. Isotopic analyses revealed that anguilliform fish occupy a very elevated predatory rank in the complex trophic chains of the seafloors of the lagoon (Brischoux et al. 2011). However, with the exception of $\mathrm{Hg}$, trace metals such as $\mathrm{Cd}, \mathrm{Co}, \mathrm{Cr}$, $\mathrm{Cs}, \mathrm{Mn}$ and $\mathrm{Zn}$ do not biomagnify under normal conditions in predator fish feeding on a piscivorous diets (Mathews et al. 2008). Finally, particular life history and physiological traits (e.g. longevity) might be involved in the resulting bioaccumulation, these issues remain undocumented however.

Considering the sedentary and phylopatric habits of the studied organisms (anguilliform fish and sea kraits) the present results can be confidently examined at a spatial scale that allows comparisons with little (or lack of) overlap among the selected sites (Figure 1). The present results revealed that important contamination by mine trace elements spreads through the lagoon, from the coast to the barrier reef following a decreasing concentration gradient (Figure 4). The fish sampled close to Nouméa are exposed to industrial (notably SLN Ni factory) and urban contaminations; they displayed highest concentrations for mine trace elements (e.g. Ni) and for several urban trace elements (e.g. Ag; Martin et al. 1988; SañudoWillhelmy and Flegal; 1992; Cossa et al. 1993). These results are in agreement with previous works on algae, bivalves and coral groupers collected in urban areas (Hédouin et al. 2009; Metian et al. 2008a, 2013). Therefore, anguilliform fish seem to accurately reflect coastal 
industrial and urban contaminations. However, the present results partly contrast with those of Metian et al. (2013) that did not find spatial differences in $\mathrm{Co}, \mathrm{Cr}$ and $\mathrm{Ni}$ concentrations in the tissues of the coral grouper Plectropomus leopardus from different coastal sites of the southern New Caledonia lagoon. The anguilliform fish from the most remote area approximately $20 \mathrm{~km}$ offshore near the barrier reef (Amédée) and located in a pass, were the less contaminated by trace elements associated with nickel industry. Investigations in deep pelagic species indicate that contamination drops sharply out of the lagoon (Bustamante et. 2000; Pernice et al. 2009; Bustamante et al. 2003). The lagoon is characterized by shallow waters $(15 \mathrm{~m}$ on average in the sampled area) whilst very deep waters occur after the barrier reef (depth $>500 \mathrm{~m} \sim 3 \mathrm{~km}$ after the drop-off) allowing the dilution of contaminated waters.

Unexpectedly, relatively high contamination levels for several urban trace elements were also recorded in Signal and Amédée that are respectively situated $15 \mathrm{~km}$ and $20 \mathrm{~km}$ offshore. These two islets have been used during decades as rubbish tips and impacted by oil contamination (e.g. large petrol tanks are still stored on Amédée); the garbage produced by important tourist activity (hundreds of tourists per day) are still directly burned in open fires. In both sites large rubbish layers buried during the Second World War (and later) are regularly excavated by high tides (pers. obs). Sea kraits take approximately one third of their prey in the vicinity of their home islet (in a $<1 \mathrm{~km}$ radius, Brischoux et al. 2007), local contamination remains possible. Alternatively, trace elements such as Fe or $\mathrm{Zn}$ that can be relatively abundant in the absence of anthropogenic contamination might naturally accumulate in anguilliform fish (Eisler 2010). Further investigations are needed to evaluate the influence of human activity versus natural processes on the concentrations these different trace elements.

The great contamination variability observed for several trace elements was expected; analyses were based on samples collected over a large spatial gradient (and with six years interval between the two sampling periods). Further, different fish species were pooled to perform several analyses. Finer assessment is thus necessary to take into account the respective ecology and biology of each fish species. Thus, several ecological and methodological issues should be addressed (e.g. regarding the foraging ecology of anguilliform fish) to better interpret the concentration levels and variations observed. However, no species effect was detected for major mine trace elements whereas elevated values were observed in all fish species. Moreover, the fish containing the highest quantity of $\mathrm{Ni}$ also exhibited the highest concentrations of $\mathrm{Co}, \mathrm{Cr}$, and $\mathrm{Mn}$ and they were found in the area situated near one of the main nickel factory. Thus major conclusions were robust and 
anguilliform fish might be appropriate candidates to monitor contamination by trace elements associated with $\mathrm{Ni}$ exploitation.

Although the respective contribution of multiple sources on contamination in benthic predators such as anguilliform fish cannot be tease apart, the present results show that contamination by trace elements is a large scale problem largely underestimated in a major biodiversity hotspot. Several axes for future researches can be proposed. Trace element levels should be measured across trophic chains, from sediments to sea kraits. Using the network of sea krait populations (Bonnet 2012), a large spatial scale investigation would permit such assessment and to extent analyses to POPs and ultimately to examine consequences on populations (Cavanagh et al. 1999; Bishop and Rouse 2006; Burger et al. 2007, RezaieAtagholipour et al. 2012). New Caledonian waters are naturally enriched in different trace elements, and many organisms may well be adapted to high trace element concentrations. Alternatively, fast developing urbanization and mining activities may cause deleterious pollution.

Acknowledgments: We thank I. Ineich (France), E. Potut (Scaphca) and R. Shine (University of Sydney) and many field volunteers. The study was carried out under permits 6024179/DRN/ENV, 6024-3601/DRN/ENV and 503/DENV/SMER issued by the DENV New Caledonia. MJB was funded by a UNC-ED fellowship and the Total Foundation. Assays were financially supported by LIENSs laboratory.

\section{References}

Abrams RW, Abrams MD, Schein M. Diurnal observations on the behavioural ecology of Gymnothorax moringa (Cuvier) and Muraena miliaris (Kaup) on a Caribbean coral reef. Coral Reefs 1983; 1: 185-192.

Ambatsian P, Fernex F, Bernat M, Parron C, Lecolle J. High metal inputs to closed seas: the New Caledonian Lagoon. Journal of Geochemical Exploration 1997; 59: 59-74

Ashraf MA, Maah MJ, Yusoff I. Bioaccumulation of heavy metals in fish species collected from former tin mining catchments. International Journal of Environmental Research 2012; 6: 209-218.

A2EP.Agence pour l'Eau et l'Environnement du Pacifique. Macro-schéma d'assainissement de la Nouvelle-Calédonie. Rapport d'Etape 1, 061/08/E/NC, 2009. pp 135.

Bird ECF, Dubois JP, Iltis JA. The impact of opencast mining on the rivers and coasts of New Caledonia. The United Nation University, NRTS-25/UNUP-505. 1984, 53p. 
Bishop CA, Rouse JD. Polychlorinated Biphenyls and Organochlorine Pesticides in Plasma and the Embryonic Development in Lake Erie Water Snakes (Nerodia sipedon insularum) from Pelee Island, Ontario, Canada (1999). Archives of Environmental Contamination and Toxicology 2006; 51: 452-57.

Böhlke EB, McCosker JE, Smith DG. Muraenidae. In: K.E. Carpenter and V.H. Niem, Eds. FAO species identification guide for fishery purposes. The living marine resources of the Western Central Pacific 1999; 3: 1643-1657. FAO, Rome.

Bonnet X. Long term field study of sea kraits in New Caledonia: fundamental and conservation issues. Integrative and Comparative Biology 2012; 52: 281-295.

Brischoux F, Bonnet X, Shine R. Foraging ecology of sea kraits (Laticauda spp.) in the NeoCaledonian lagoon. Marine Ecology Progress Series 2007; 350: 145-151.

Brischoux F, Bonnet X, Shine, R. Determinants of dietary specialization: a comparison of two sympatric species of sea snakes. Oikos 2009a; 118: 145-151.

Brischoux F, Bonnet X, Legagneux P. Are sea snakes pertinent bio-indicators for coral reefs? A comparison between species and sites. Marine Biology 2009b; 156: 1985-1992.

Brischoux F, Bonnet X, Pinaud D. Fine scale site fidelity in sea kraits: implications for conservation. Biodiversity and Conservation 2009c; 18: 2473-2481.

Brischoux F, Bonnet X, Cherel Y, Shine R. Isotopic signatures, foraging habitats and trophic relationships between fish and reptile, top-predators on the coral reefs of New Caledonia. Coral Reefs 2011; 30: 155-165.

Burger J. Bioindicators: a review of their use in the environmental literature 1970-2005. Environmental Bioindicators 2006; 1: 136-44.

Burger J, Campbell KR, Murria S, Campbell TS, Gaines KF, Jeitner C, Shukla T, Burke S, Gochfeld M. Metal in blood, muscle and liver of water snakes (Nerodia spp.) from New Jersey, Tennessee and South Carolina. Science of the Total Environment 2007; 373: 55663.

Bustamante P, Grigioni S, Boucher-Rodoni R, Caurant F, Miramand P. Bioaccumulation of 12 trace elements in the tissues of the nautilus Nautilus macromphalus from NewCaledonia. Marine Pollution Bulletin 2000; 40 (8): 688-696.

Bustamante P, Garrigue C, Breau L, Caurant F, Dabin W, Greaves J, Dodemont R. Trace elements in two odontocetes species (Kogia breviceps and Globicephala macrorhynchus) stranded in New Caledonia (South Pacific). Environmental Pollution 2003; 124: 263-71.

Bustamante P, Lahaye V, Durnez C, Churlaud C, Caurant F. Total and organic Hg concentrations in cephalopods from the North East Atlantic waters: influence of 
geographical origin and feeding ecology. Science of the Total Environment $2006 ; 368$ : 585-596.

Callender E, Rice KC. The urban environmental gradient: anthropogenic influences on the spatial and temporal distributions of lead and zinc in sediments. Environmental Science and Technology 2000; 34: 232-238.

Cantin NE, Negri AP, Willis BL. Photoinhibition from chronic herbicide exposure reduces reproductive output of reef-building corals. Marine Ecology Progress Series 2007; 344: 81-93.

Cavanagh JE, Burns KA, Brunskill GJ, Coventry RJ. Organochlorine pesticide residues in soils and sediments of the Herbert and Burdekin River regions, north Queensland, implications for contamination of the Great Barrier Reef. Marine Pollution Bulletin 1999; 39: $367-75$.

Chouvelon T, Warnau M, Churlaud C, Bustamante P. Hg concentrations and related risk assessment in coral reef crustaceans, molluscs and fish from New Caledonia. Environmental Pollution 2009; 157: 331-340.

Cossa D, Elbaz-Poulichet F, Gnassia-Barelli M, Roméo M. Le plomb en milieu marin, biogéochimie et écotoxicologie. Repères océan 1993 ; 3, IFREMER.

Denton, G.R.W., Burdon-Jones, C. Trace metals in fish from the Great Barrier Reef. Marine Pollution Bulletin 1986; 42: 224-232.

Eisler R. Chapter 3: Fishes. In: Eisler, R., Compendium of trace metals and marine biota: Volume 2: Vertebrates. Elsevier Science, New York, 2010; pp. 39-221.

Fauvel T, Brischoux F, Briand MJ, Bonnet X. Do researchers impact their study populations? Assessing the effect of field procedures in a long term population monitoring of sea kraits. Amphibia Reptilia 2012; 33: 365-372.

Garcin M, Baills A, Le Cozannet G, Bulteau T, Auboin AL, Sauter J. Pluri-decadal impact of mining activities on coastline mobility of estuaries of New Caledonia (South Pacific). Journal of Coastal Research, Special Issue 2013; 65: 494-499.

Gopal V, Parvathy S, Balasubramanian PR. Effect of heavy metals on the blood protein biochemistry of the fish Cyprinus carpio and its use as a bio-indicator of pollution stress. Environmental Monitoring and Assessment 1997; 48: 117-124.

Hao Y, Chen L, Zhang X, Zhang D, Zhang X, Yu Y, Fu J. Trace elements in fish from Taihu Lake, China: Levels, associated risks, and trophic transfer. Ecotoxicology and Environmental Safety 2013; 90: 89-97. 
Hédouin L, Pringault O, Metian M, Bustamante P, Warnau M. Nickel bioaccumulation in bivalves from the New Caledonia lagoon: seawater and food exposure. Chemosphere 2007; 66: 1449-1457.

Hédouin L, Bustamante P, Fichez R, Warnau M. The tropical brown alga Lobophora variegata as a bioindicator of mining contamination in the New Caledonian lagoon: a field transplantation study. Marine Environmental Research 2008; 66: 438-444.

Hédouin L, Bustamante P, Churlaud C, Pringault O, Fichez R, Warnau M. Trends in concentrations of selected metalloid and metals in two bivalves from the SW lagoon of New Caledonia. Ecotoxicology and Environmental Safety 2009; 72: 372-381.

Hédouin L, Pringault O, Bustamante P, Fichez R, Warnau M. Transplantation experiments for the validation of two tropical marine bivalves as bioindicators of mining contamination in the New Caledonian lagoon. Water Research 2011; 45: 483-496.

Ineich I, Bonnet X, Brischoux F, Kulbicki M, Séret B, Shine R. Anguilliform fishes and seakraits: neglected predators in coral-reef ecosystems. Marine Biology 2007; 151: 793-802.

Jeffree RA, Warnau M, Teyssié JL, Markich SJ. Comparison of the bioaccumulation from seawater and depuration of heavy metals and radionuclides in the spotted dogfish Scyliorhinus canicula (Chondrichthys) and the turbot Psetta maxima (Actinopterygii: Teleostei). Science of The Total Environment 2006; 368: 839-852,

Lewis SE, Brodie JE, Bainbridge ZT, Rohde KW, Davis AM, Masters BL, Maughan M, Devlin MJ, Mueller JF, Schaffelke B. Herbicides: a new threat to the Great Barrier Reef. Environmental Pollution 2009; 157: 2470-84.

Lewis SE, Schaffelke B, Shaw M, Bainbridge ZT, Rohde KW, Kennedy K, Davis A.M., Masters BM, Devlin MJ, Mueller JF, Brodie JE. Assessing the additive risks of PSII herbicide exposure to the Great Barrier Reef. Marine Pollution Bulletin 2012; 65: 280-291.

Manheim FT. Marine cobalt resources. Science 1986; 232: 600-608.

Martin M, Stephenson MD, Smith DR, Gutierrez-Galindo EA, Flores Munoz G. Use of silver in mussels as a tracer of domestic wastewater discharge. Marine Pollution Bulletin 1988; 19: 512-520.

Massabuau JC, Campbell P, Monnin C, Roux B. Etude de l'impact potentiel du rejet de l'effluent Goro Nickel dans le lagon sud de Nouvelle - Calédonie 2006; PP 61.

Mathews T, Fisher NS, Jeffree RA, Teyssié JL. Assimilation and retention of metals in teleost and elasmobranch fishes following dietary exposure. Marine Ecology Progress Series 2008; 360: 1-12. 
Metian M, Bustamante P, Hédouin L, Warnau M. Accumulation of trace elements in the tropical scallop Comptopallium radula from coral reefs in New Caledonia. Environmental Pollution 2008; 152: 543-552.

Metian M, Warnau M, Chouvelon T, Pedraza F, Rodriguez Y, Baena A, Bustamante P. Trace element bioaccumulation in reef fish from New Caledonia: influence of trophic groups and risk assessment for consumers. Marine Environmental Research 2013; 87-88C: 26-36.

Mihaylov I, Krause E, Colton DF, Okita Y, Duterque JP, Perraud JJ. The development of a novel hydro-metallurgical process for nickel and cobalt recovery from Goro laterite ore. CIM Bulletin 2000; 93: 124-130.

Monniot F, Martoja R, Monniot C. Cellular sites of iron and nickel accumulation in ascidians related to the naturally and anthropic enriched New Caledonian environment. Annales de l'Institut Océanographique 1994; 70: 205-216.

Myers N, Mittermeier RA, Mittermeier CG, da Fonseca GAB, Kents J. Biodiversity hotspots for conservation priorities. Nature 2000; 403: 853-858.

Ouillon S, Douillet P, Lefebvre JP, Le Gendre R, Jouon A, Bonneton P, Fernandez JM, Chevillon C, Magand O, Lefèvre J. Circulation and suspended sediment transport in a coral reef lagoon: The south-west lagoon of New Caledonia. Marine Pollution Bulletin 2010; 61: $7-12$.

Parkinson R. Nickel plating and electroforming: Essential industries for today and the future. NiDI Technical Series No 10088 - Nickel Institute. 2005, 30p.

Pernice M, Boucher J, Boucher-Rodoni R, Joannot P, Bustamante P. Comparative bioaccumulation of trace elements between Nautilus pompilius and N. macromphalus (Cephalopoda: Nautiloidea) from Vanuatu and New Caledonia. Ecotoxicology and Environmental Safety 2009; 72: 365-371.

Pesin E, Blaize S, Lacoste D. Atlas climatique de la Nouvelle Calédonie, Météo France. Nouméa, New Caledonia. 1995.

Rainbow PS. Biomonitoring of heavy metal availability in the marine environment. Marine Pollution Bulletin 1995; 31: 183-192.

Reed RN, Shine R, Shetty S, Cogger H. Sea kraits (Squamata: Laticauda spp.) as a useful bioassay for assessing local diversity of eels (Muraenidae, Congridae) in the western Pacific Ocean. Copeia 2002; 2002: 1098-1101.

Rezaie-Atagholipour M, Riyahi-Bakhtiari A, Sajjadi M, Kong Yap C, Ghaffari S, EbrahimiSirizi Z, Ghezellou P. Metal concentrations in selected tissues and main prey species of the 
annulated sea snake (Hydrophis cyanocinctus ) in the Hara Protected Area, northeastern coast of the Persian Gulf, Iran. Marine Pollution Bulletin 2012; 64: 416-421.

Rhind SM. Anthropogenic pollutants: a threat to ecosystem sustainability? Philosophical Transactions of the Royal Society of London B 2009; 364:3391-3401.

Rogers CS. Responses to coral reefs and reef organisms to sedimentation. Marine Ecology Progress Series 1990; 62: 185-202.

Sañudo-Willhelmy S, Flegal R. Anthropogenic silver in the Southern California Bight: a new tracer of sewage in coastal waters. Environmental Science and Technology 1992; 26: $2147-2151$.

Smith DG. Myrocongridae: thin morays. In K.E. Carpenter and V.H. Niem Eds. FAO species identification guide for fishery purposes. The living marine resources of the Western Central Pacific. 1999a; 3: 1641-1642. FAO, Rome.

Smith DG. Congridae: Conger eels. In K.E. Carpenter and V.H. Niem Eds. FAO species identification guide for fishery purposes. The living marine resources of the Western Central Pacific 1999b; 3: 1680-1688. FAO, Rome.

Smith DG, McCosker JE. Ophichthidae: snake eels, worm eels. In: Carpenter K.E., Niem V.H. (Eds.). FAO species identification guide for fishery purposes. The living marine resources of the Western Central Pacific 1999; 3: 1662-1669. FAO, Rome.

van der Oost R, Beyer J, Vermeulen NPE. Fish bioaccumulation and biomarkers in environmental risk assessment: a review. Environmental Toxicology and Pharmacology 2003; 13: 57-149.

Walker DI, Ormond RFG. Coral death from sewage and phosphate pollution at Aqaba, Red Sea. Marine Pollution Bulletin 1982; 13: 21-25. 
Table1. List of the anguilliform fish sampled (second column) for their trace element content. Several fish were not accurately identified (e.g., head + half of the body missing). Predator refers to the sea krait from which the fish were obtained: LS stands for Laticauda saintgironsi; LL stands for Laticauda laticaudata.

\begin{tabular}{llrr}
\hline Year & Fish species & \multicolumn{2}{c}{ Predator species } \\
\cline { 3 - 4 } & & LS \\
\hline 2005 & Conger spp. & 3 & 6 \\
2011 & Conger spp. & 2 & 15 \\
2005 & Gymnothorax albimarginatus & 0 & 9 \\
2011 & G. chilospilus & 11 & 1 \\
2005 & G. fimbriatus & 8 & 0 \\
2005 & G. margaritoforus & 10 & 0 \\
2005 & Myrophis microchir & 0 & 10 \\
2005 & Unidentified & 2 & 2 \\
2011 & Unidentified & 0 & 1 \\
& Total & 36 & 44 \\
\hline
\end{tabular}


Table 2. List of the trace elements assayed in the anguilliform fish (first column), all fish species pooled. Sample size (N), mean values (expressed in $\mu \mathrm{g} g-1$ ), standard deviation (SD), coefficient of variation (CV, expressed in \%) and range (min-max) are provided.

\begin{tabular}{llcrcc}
\hline Element & $\mathrm{N}$ & Mean $\pm \mathrm{SD}$ & $\mathrm{CV}$ & Min & Max \\
\hline $\mathrm{Ag}$ & 80 & $0.052 \pm 0.154$ & 296 & 0.005 & 1.35 \\
$\mathrm{As}$ & 80 & $10.5 \pm 18.2$ & 173 & 0.1 & 118 \\
$\mathrm{Cd}$ & 80 & $0.285 \pm 0.266$ & 83 & 0.010 & 1.39 \\
$\mathrm{Co}$ & 80 & $0.15 \pm 0.09$ & 60 & 0.34 & 0.68 \\
$\mathrm{Cr}$ & 80 & $5.53 \pm 6.99$ & 126 & 0.11 & 35.7 \\
$\mathrm{Cu}$ & 80 & $5.2 \pm 3.8$ & 73 & 0.9 & 19.2 \\
$\mathrm{Fe}$ & 80 & $63 \pm 47$ & 75 & 11 & 235 \\
$\mathrm{Hg}$ & 30 & $0.065 \pm 0.034$ & 52 & 0.015 & 0.152 \\
$\mathrm{Mn}$ & 80 & $4.3 \pm 3.1$ & 72 & 0.5 & 19.9 \\
$\mathrm{Ni}$ & 80 & $2.84 \pm 3.38$ & 119 & 0.39 & 18.0 \\
$\mathrm{~Pb}$ & 80 & $0.438 \pm 0.636$ & 145 & 0.010 & 4.88 \\
$\mathrm{Se}$ & 30 & $1.78 \pm 0.94$ & 53 & 0.67 & 4.65 \\
$\mathrm{~V}$ & 30 & $0.43 \pm 0.12$ & 28 & 0.29 & 0.83 \\
$\mathrm{Zn}$ & 80 & $77 \pm 34$ & 44 & 22 & 158 \\
\hline
\end{tabular}




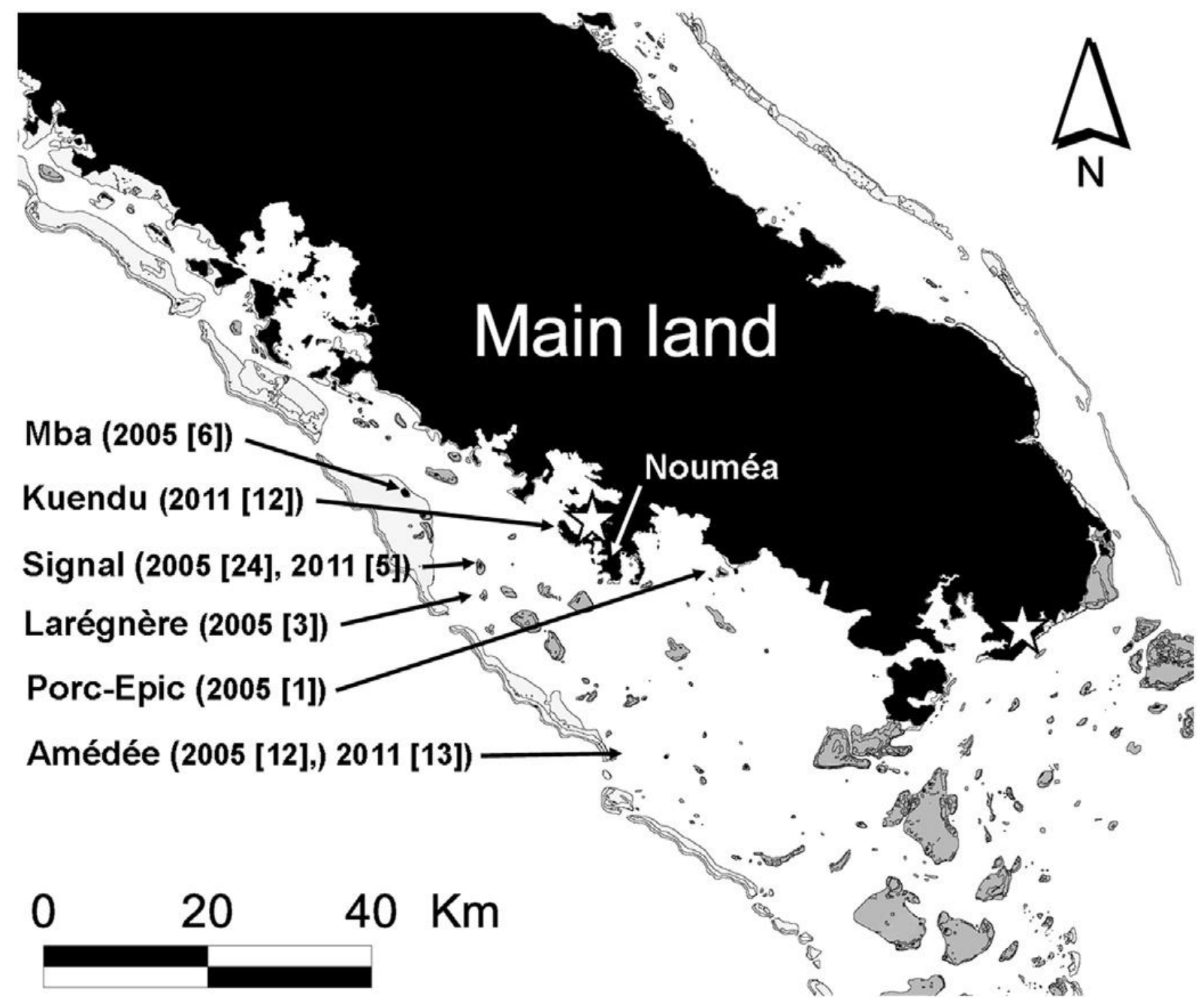

Figure 1. Map of the study area. In each study site sampling year and sample size $(\mathrm{N})$ are indicated. The two stars show two nickel factories (SLN near Nouméa and Goro Nickel at the southern tip of the main land). Black areas indicate emergent land (mainland and islands); grey areas represent coral reef flats. The barrier reef and other fringing reefs are represented by light grey areas. Kuendu and Porc Epic are close to the mainland (Costal Sites), Amédée is near the barrier reef (Barrier Reef Site), and the others (e.g. Signal) are in an intermediate situation (Mid-Lagoon Sites). 

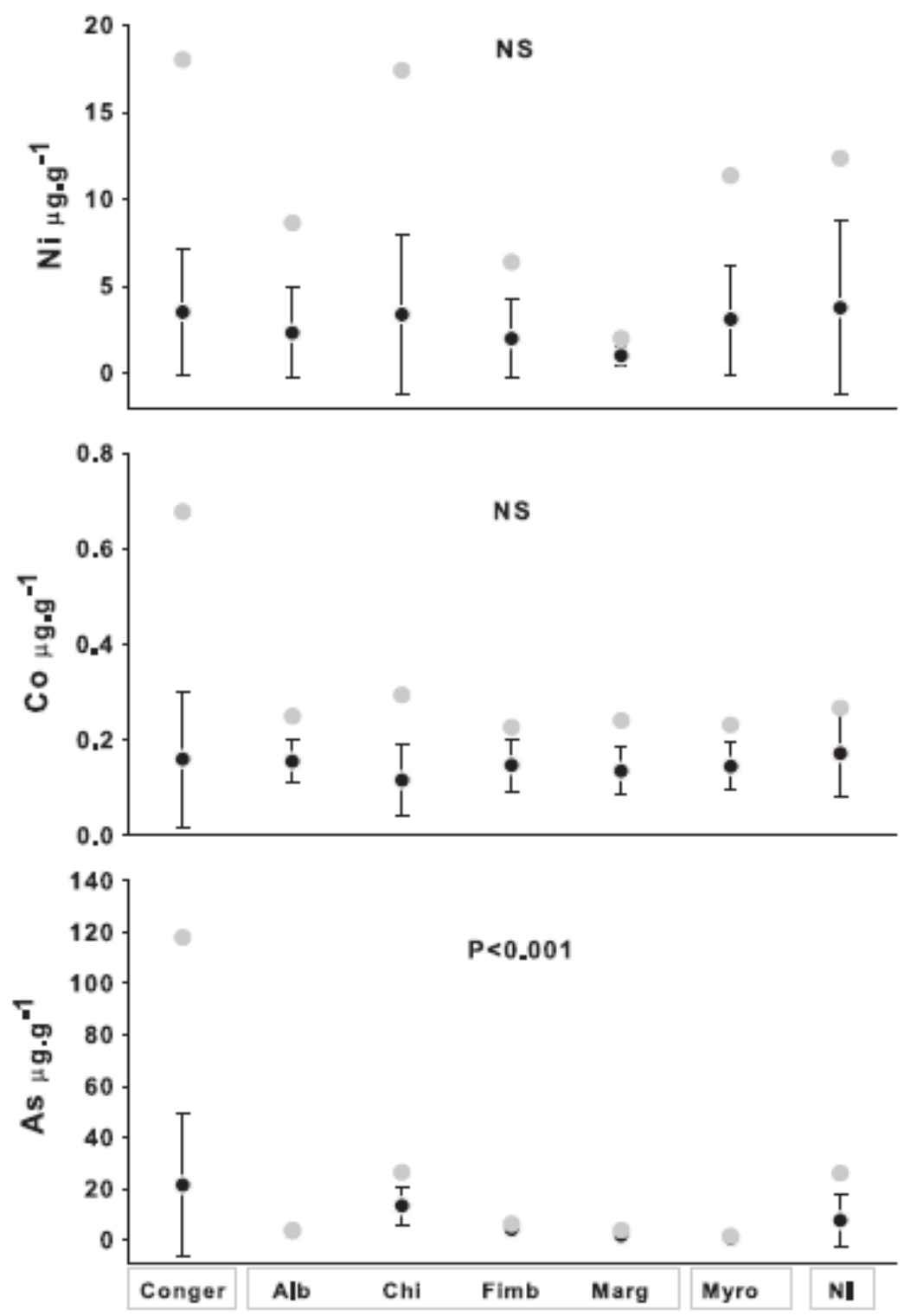

Figure 2. Comparisons between mean $( \pm \mathrm{SD}$; black symbols and error bars) and maximal values (grey circles) of several trace elements measured in the muscles of different species of anguilliform fish. Fish were grouped as follow: congers-eels (Conger), Moray-eels (Alb to Marg), Snake-eels (Myro) and non identified (NI). Full names and sample size are provided in Table 1. Although significant differences were detected between fish species for several trace element (e.g. As, $\mathrm{P}<0.001$, see text) or not for others (e.g. Ni, Co, $\mathrm{P}<0.05$, see text), important overlapping was observed in all cases (not all trace elements displayed). NS stands for non significant. 

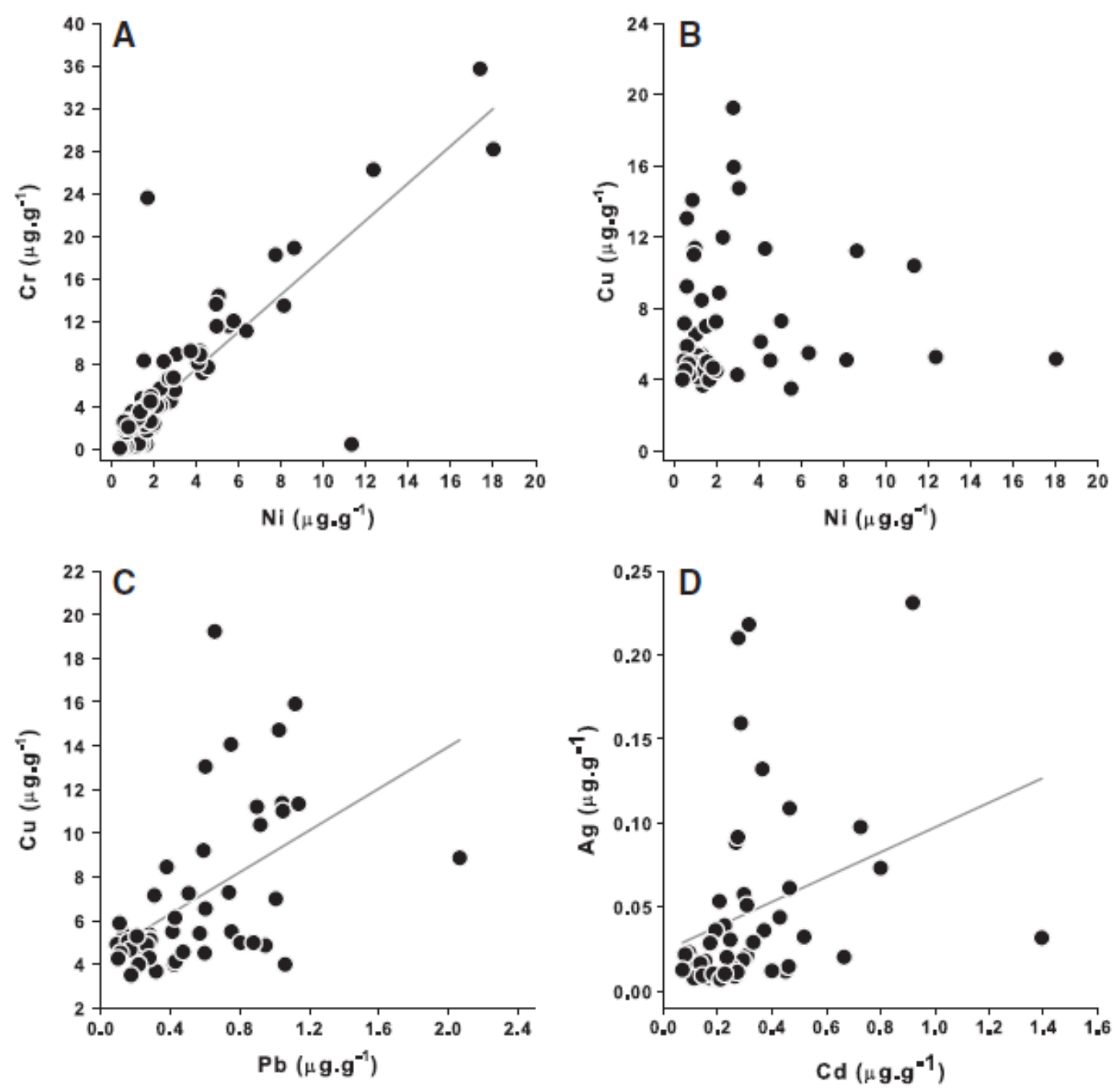

Figure 3. Relationships between the concentrations of several trace elements measured in 80 anguiliform fish. Graph-A displays significant correlation between two trace elements typically released in the environment by nickel industry ( $\mathrm{Ni} \& \mathrm{Cr}$ ), the dashed grey lines indicates high level threshold according to the literature. Graph-B displays a lack of relationship between a $\mathrm{Ni}$ and $\mathrm{Cu}$ respectively associated with mining versus urban activities. The bottom graphs (C \& D) display significant correlations between trace elements typically associated with urban activity. 

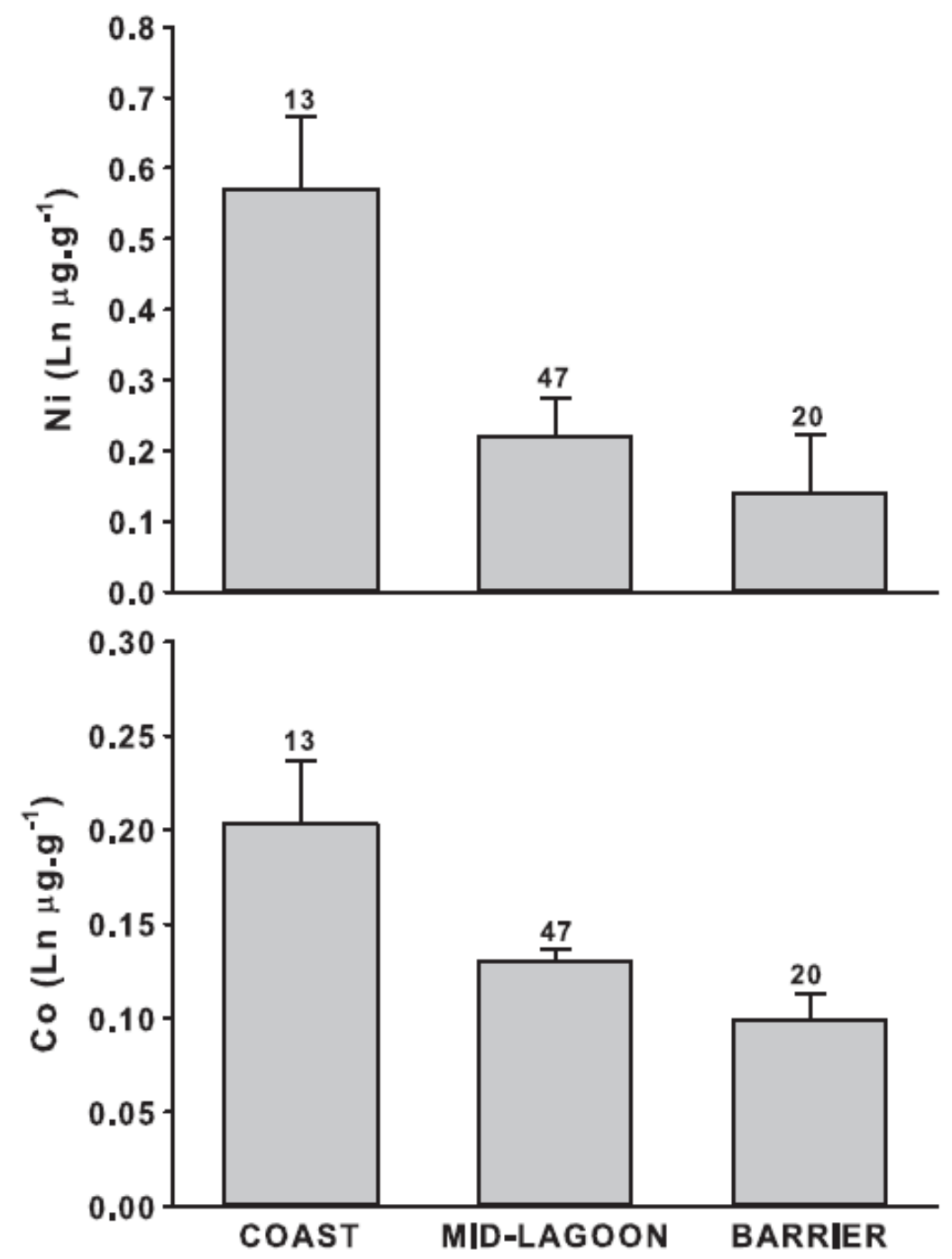

Figure 4. Mean concentration (Log transformed) of two trace elements associated with mining activity ( $\mathrm{Ni}$ and $\mathrm{Co}$ ) measured in fish collected in costal, mid-lagoon and barrier reef sites (see figure 1 for geographical positions). Mean are expressed with their standard error and sample size. 


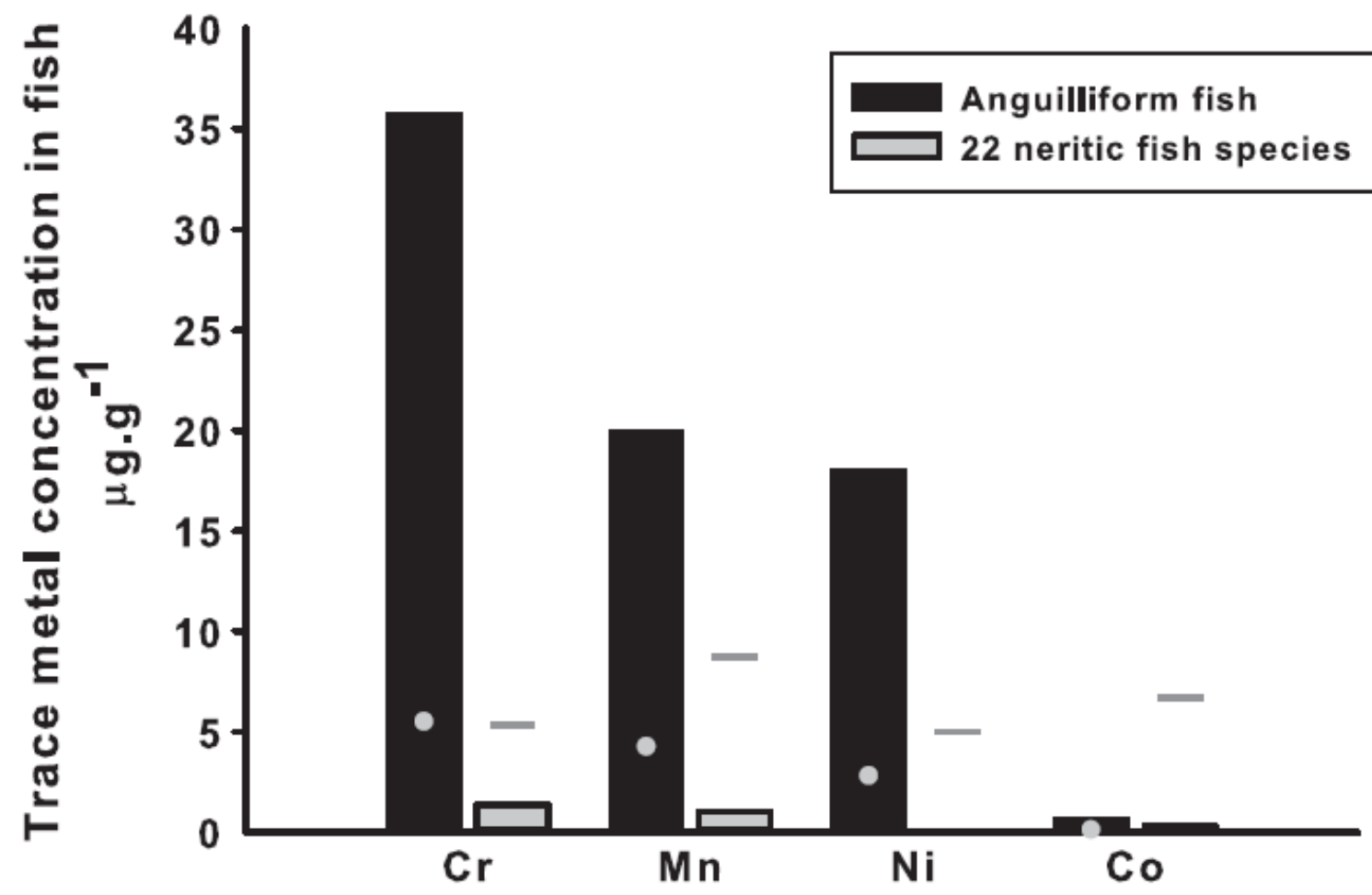

Figure 5. Comparison of the maximal concentration of four trace elements associated with mining activity ( $\mathrm{Cr}, \mathrm{Mn}, \mathrm{Ni}$ and $\mathrm{Co}$ ) measured in the muscles of anguilliform fish (black bars) versus a pool of 22 neritic fish by Metian et al. 2013 (grey bars). To facilitate comparison, the grey dots indicate mean values (not maximal) for anguillifom fish ( $\mathrm{N}=80$; muscles); and the grey horizontal lines indicate the maximal values recorded in the liver of the pool of 22 neritic fish studied by Metian et al. 2013. 